\section{Acute Gastroenteritis}

SIR,-I would like to comment on three aspects of your very concise and topical leading article headed "Acute Gastroenteritis" (13 January, p. 70).

Although certain specific strains of Escherichia coli are undoubtedly concerned in the aetiology of gastroenteritis in young children, it is still possible that this disease is primarily a virus infection. At any rate, there is suffcient doubt to keep an open mind. Other infectious diseases such as influenza and ulcerative stomatitis have in the past been thought at first to be due to bacteria, and yet eventually a virus has been found to be responsible.

The paramount importance of adequate fluid replacement is correctly stressed, but surely it is going much too far to state that this can be done only by intravenous infusion. In my experience at least 9 out of 10 children admitted to hospital with gastroenteritis can quickly and effectively be rehydrated via the oral route. Half-strength Darrow's solution containing sodium chloride, potassium chloride, and sodium lactate, given by mouth in small frequent doses, is rapidly absorbed. A regimen of $2 \mathrm{oz}$. ( $50 \mathrm{ml}$.) every 15 minutes for the first two and a half hours, and then $2 \mathrm{oz}$. every hour for the next 10 hours, will usually result in satisfactory rehydration and restore any electrolyte imbalance. It is only in the case of the very occasional infant who continues to vomit or who is unconscious on admission that intravenous therapy is required.

The sooner correct treatment is started the better. All too often fluids are withheld, foods thickened, or glucose water given, and such measures cannot be too strongly condemned. A suitable tablet included in the National Formulary would certainly be an asset for home treatment, but the chances of this being available at the moment of need are perhaps remote. However, it is always possible to add half a teaspoonful of common salt to a pint $(500 \mathrm{ml}$.) of water in order to get a satisfactory solution for commencing treatment at home. You rightly emphasize that in such circumstances there must be close observation, as these small children can deteriorate so very quickly. - I am, etc., Department of Health, JoHN F. WARIN.
Oxford.

\section{Diagnosis of Pyelonephritis in Children}

SIR,-Your recent papers (23 December, pp. 697, 702, and 705) and leading article (23 December, p. 691) on this subject call for some comment. The authors emphasize that the correct collection of urine specimens from small children requires patience and time of an order which I believe to be beyond the resources of most of our ordinary nursery services today, and it would be impossible to conduct an adequate follow-up clinic along the lines described. Happily, the answer is in the hands of the clinician, for he can enumerate leucocytes in clean void urine to tell when there may be inflammation of the urinary tract and undertake a search for possible bacterial evidence of an infective cause for this. It has never been satisfactorily shown that bacterial infection of the urinary tract in childhood occurs without leucocyturia, and it is therefore easy to screen all children in and out of hospital to select those "at risk" of having an infection to see if the diagnosis can be confirmed or, more usually, excluded.

When leucocyturia is shown in more than one clean void specimen it may be possib'e to obtain a "clean catch" specimen by inducing reflex micturition, especially in young babies with a full bladder, ${ }^{1}$ and this should always be tried. If it fails then bladder puncture should be done. The procedure is easy and has been performed on hundreds of young infants without any complication other than occasional transient haematuria. I have performed bladder puncture on 150 leucocyturic ( $>50 / \mathrm{cu}$. mm.) infants and found a bacterial growth of $>10^{5}$ organisms $/ \mathrm{ml}$. in 18 and in each of these 18 there was bladder urine leucocyturia which could be immediately ascertained and was of invaluable help in management, especially in the outpatient clinic. All of the remaining specimens were sterile, and only a few of them contained leucocytes, in low numbers.

It is a very easy matter for the clinician to look for significant leucocyturia in all of his patients, and if a "clean catch" urine cannot be obtained from those "at risk" then bladder puncture should be performed. This is a procedure no more serious than venepuncture, which gives the cleanest specimen and most clear-cut answer. Indeed, the clinician-microscopist usualiy has the satisfaction of telling the diagnosis on the spot. I am, etc.,

\section{Department of Paediatrics, Guy's Hospital.}

\section{REFERENCB} Boehm, J. J., and Haynes, J. L., Amer. F. Dis.
Child., 1966, 111, 366.

\section{Urinary Tract Infection in Infancy}

SIR,-Your statement (23 December, p. 691) that the data of Dr. H. Braude, Professor J. O. Forfar, Dr. J. C. Gould, and Dr. J. W. McLeod (same issue, p. 697) " can now be used as a basis for reporting quantitatively cell and bacterial counts in infants" should not pass without comment.

We should like to make two points. The first concerns the validity of the table of diagnostic levels of cell and bacterial counts. Applying them to collections made in our own wards we find that $7 / 63(11 \%)$ routine bag specimens from baby girls studied by us $^{1}$ had results outside the stated normal limits, as did 2/99 baby boys. All these children were shown by suprapubic puncture to have sterile, cell-free bladder urine. Similarly, Houston's 1963 series $^{2}$ describes 77 collections of urine by clean voiding or Paul's tubing from uninfected male children. Of these, $10(13 \%)$ gave results outside Braude and colleagues' stated normal limits. One must therefore doubt the general applicability of these tables to routine urine collections.

The second point we make is: how useful are such tables in clinical work? Do they help in the urgent case ? In our experience, no. The chance of a false-positive or falsenegative result is substantial.

It is our experience that paediatricians have not been unwilling to accept diagnosis by suprapubic bladder puncture in small infants and certain urgent cases. Bladder puncture is less distressing than lumbar puncture, and indeed than many venepunctures, and we have not yet experienced (or seen reported) a complication.-We are, etc.,

$$
\begin{aligned}
& \begin{array}{l}
\text { Lambeth Hospital, } \\
\text { London S.E.1. }
\end{array} \text { PAULINE O'NeILI } \\
& \begin{array}{l}
\text { St. Thomas's Hospital, } \\
\text { London S.E.1. }
\end{array}
\end{aligned}
$$

\section{REFERENCES}

Newman, C. G. H., O'Neill, P., and Parker, A., Brit. med. F., 1967, 2, 277.
Houston, I. B., Arch. dis. Childh., 1963, 38, 600.

\section{Renal Glucose Threshold}

SIR,-Professor W. J. H. Butterfield and others (2 December, p. 505) are to be congratulated on the many useful clinical points they make from their very extensive and excellent Bedford survey for diabetes. However, I cannot agree with the deductions which led them to make the main point in this paper. By their own definition the presence of glucose in the urine is not detected below $100 \mathrm{mg} . / 100 \mathrm{ml}$. Indeed, the manufacturers (Ames Co.) wisely do not claim that Clinistix is reliable below this concentration and are careful to point out the inhibitory effects of ascorbic acid, $\mathrm{pH}$, temperature reduction, etc. Because a more sensitive measure of glucose in the urine was not employed (such as paper chromatography) it would have been quite possible for a subject to void a concentration of g'ucose still undetected by Clinistix but contained in such a volume of urine as to represent more total glucose passed than a subject with a detectable concentration by Clinistix and smaller urine volume. We are not told the volume of urine voided in the test samples.

The oral glucose tolerance test, as applied in this survey, with blood samping at halfhourly intervals, is probably valid as a test for diabetes mellitus in diabetics. The results should be interpreted with caution when applied in the same way to normal people. This is especially so when it is used to show some other physiological function for which it was never designed as a test. Because of the many factors influencing absorption and utilization of giucose the rise and fall of blood glucose in the normal child and adult can be very rapid or relatively slow, depending on circumstances.

It is not posstble to show with confidence peak values of glucose reached in the blood unless a continuous sampling method is used. The authors say: “. . . the presence of glucose and not its concentration will be considered here. It should be pointed out, under these circumstances, that from the presence of glycosuria we can only deduce that the renal threshold was lower than the peak value found, and that in the absence of glycosuria the renal threshold was higher than the peak value." It should be pointed out that the opposite is just as likely to be true. It is clear that because of the method used the true peak of blood glucose could be missed in many patients, and therefore the renal threshold may have been higher than the value actually found in those patients with glycosuria. It is equally clear, because of the insensitive method used in the urine, that the absence of significant amounts of glucose is not proved (more especially as we do not know the urine volumes). Therefore the renal threshold could just as easily be lower than the peak value actually found by the others. 